\title{
Craniocervical junction abnormalities in northeast Brazilian population
}

\author{
Anormalidades da junção crânio-cervical na população do nordeste brasileiro
}

Arnolfo de Carvalho Neto ${ }^{1,2}$, Débora Brighente Bertholdo ${ }^{1,3}$

\author{
Clínica de Imagem DAPI, Curitiba \\ PR, Brasil; \\ Universidade Federal do Paraná, \\ Curitiba PR, Brasil; \\ ${ }^{3}$ Universidade Federal do Paraná, \\ Hospital de Clínicas, Curitiba \\ PR, Brasil.

\section{Correspondence:} \\ Arnolfo de Carvalho Neto; \\ Rua Rolfe Mertens, 289; \\ 80520-670 Curitiba PR, Brasil; \\ E-mail:arnolfo@gmail.com \\ Conflict of interest: \\ There is no conflict of interest to \\ declare. \\ Received 12 June 2017 \\ Accepted 19 June 2017
}

\section{(c) BY}

$\mathrm{T}$

he older radiologists will remember how frequent was reporting routine plain skull images to evaluate craniocervical junction, which required drawing angles and lines trying to identify the presence of platibasia and basilar invagination and how often the overlap of structures required complementation with planigraphy.

Computed tomography did not change this reality at once because old equipment allowed only axial imaging and the reconstructions were only satisfactory after the injection of intrathecal iodinated contrast.

The advent of magnetic resonance imaging (MRI) however changed radically the evaluation of the craniocervical junction since we could directly visualize not only the bone structures, but also the medulla and the spinal cord, mainly in the sagittal plane. So the main changes related to skull base abnormalities, such as Chiari syndrome (type 1) and syringohydromielia can be diagnosed identifying the position and shape of the cerebellar tonsils as well as the presence of intramedullary cyst. Other problems associated with skull base abnormalities such as cranial nerves paralysis, drop attacks and headache despite not so straightforward could also be evaluated by MRI.

Most neuroradiologists find unnecessary to measure the angles of the skull base or the position of the odontoid process in relation to the foramen magnum, so these laborious procedures were almost forgotten.

Older radiologists will also remember that these changes were supposedly more frequent in Northeastern Brazilians, whose archetypal biotype was short neck and brachycephaly ("flat head"), most often attributed to genetic factors and sometimes to childhood deficiencies such as rickets. It was known that neurosurgeons from the Northeast had the largest number cases of craniocervical joint surgeries to correct these defects ${ }^{1}$.

There was strong support for these statements in medical literature. Silva et al. ${ }^{1}$, a group of physicians from Northeast, wrote the paper with most cases of neurosurgical treatment of occipitovertebral malformations present in the literature, including 242 patients with platibasia (213 of them with Chiari type 1 malformation).

Barros et al. ${ }^{2}$ in a study of 66 patients from Northeast of Brazil with basilar impression and Chiari malformation found a predominance of white patients, and postulated that the high prevalence of skull base abnormalities in Northeast were caused by the Dutch colonization, once these conditions are also more common in Netherlands. However, some historical facts go against this theory3. The skull abnormalities are seen in the whole territory of Northeastern Brazil, beyond the area of Dutch dominion, the period of time of this dominion was short and Dutch women were brought from the Dutch court for sexual satisfaction, reducing miscegenation. Moreover, archaeological excavations in Pernambuco found humans skeletons dated from 2,000 years ago ${ }^{3}$. Short and wide cranium and high faces characterized the cranial morphology of this era. Therefore this tendency for braquicephaly, platibasia and basilar invagination on Northeastern Brazilians is believed to be inherited from pre- historic ancestors.

In this issue of Arquivos de Neuropsiquiatria Frade et al. ${ }^{4}$ revived those concepts measuring Chamberlain's line, that evaluate basilar invagination, and median clivus-canal and Welcher basal angles, that evaluate platibasia, utilizing MRI in asymptomatic subjects of the Brazilian Northeast. They found a tendency to platibasia and basilar invagination on their population. However, as the authors say on their report, there still are some controversies about the normal measurements, particularly for basilar invagination ${ }^{5}$ and we do 
not have equivalent measurements of these parameters on others regions of Brazil.

Anyway while we wait for comparative population studies to accept or reject old concepts about these anthropological characteristics of our population, for us practical neuroradiologists, the question is simpler. Is it worth to reintroduce the measurements and angles in the evaluation of the base of the skull in our daily practice?

\section{References}

1. Silva JA, Brito JC, Nóbrega PV, Costa M Souza AB. [Asilar impression and Arnold-Chiari malformation: surgical findings in 260 cases]. Arq Neuropsiquiatr. 1994;52(3):363-9. Portuguese. https://doi.org/10.1590/S0004-282X1994000300013

2. Barros MC, Farias W, Ataíde L, Lins S. Basilar impression and Arnold-Chiari malformation: a study of 66 cases. J Neurol Neurosurg Psychiatry. 1968;31(6):596-605.

3. Vidal CH, Silva JC, Lins CJ, Brainer-Lima AM, Valença MM. Craniovertebral junction malformation in Northeastern Brazil: the myth of the Dutch colonization. Arq Neuropsiquiatr. 2013;71(6):405-7. https://doi.org/10.1590/0004-282X20130047

4. Frade HC, França CCNL, Nascimento JJC, Holanda MMA, Silva Neto EJ, Araújo Neto SA. Cranio-vertebral transition assessment by magnetic resonance imaging in a sample of a northeast Brazilian population. Arq Neuropsiquiatr. 2017;75(7):419-23. https://doi.org/10.1590/0004-282X20170071

5. Smoker WR. Craniovertebral junction: normal anatomy, craniometry, and congenital anomalies. Radiographics. 1994;14(2):255-77. https://doi.org/10.1148/radiographics.14.2.8190952 